\title{
Critical success factors for new dishes in gastronomic offer of Belgrade restaurants
}

\author{
Aleksandar Božić ${ }^{1 *}$, Srđan Milošević \\ ${ }^{1}$ High School of Touris m, Belgrade, Serbia \\ ${ }^{2}$ University Educons, Faculty for Sport and Tourism - TIMS, Novi Sad, Serbia
}

\begin{abstract}
The subject of the research of this paper is the success of new dishes in the gas tronomic offer of Belgrade restaurants, presented through critical success factors (CSFs) that can influence it. The aim was to analyze CSFs of new dis hes in mentioned restaurants. The initial as sumption was that the success of new dis hes depends on various factors, which resulted in developing a general research question: What factors are important for the success of new dishes in the gastronomic offer of a restaurant? To achieve a high level standards in the restaurant industry and boost competitiveness, businesses have to keep up with modern trends and introduceinnovative business approaches. The questionnaire consisted of three sections: managers' profile, the restaurant profile and CSFs. The managers of Belgrade restaurants $(\mathrm{N}=64)$ were asked to rank ten different CSFs using the Likert scale. According to theiropinions, seven CSFs were found to be very important for the success of new dishes.
\end{abstract}

Keywords: Belgrade restaurants, critical success factors, new dishes

JEL classification: L83

\section{Kritični faktori uspešnosti novih jela u gastronomskoj ponudi beogradskih restorana}

Sažetak: Predmet is traživanja ovog rada je uspešnost novih jela u gastronoms koj ponudi beogradskih restorana, prikazana kroz kritične faktore uspešnosti (KFU) koji na to mogu uticati. Cilj je bio da se analiziraju KFU novih jela u ovim restoranima. Polazna pretpostavka je bila da uspešnost novih jela zavisi od različitih faktora, iz čega je proizašlo i opšte is traživačko pitanje: Koji faktori su značajni za uspešnost novih jela u gas tronomskoj ponudi restorana? Da bi se ostvario postavljeni cilj i dao odgovor na postavljeno istraživačko pitanje, bilo je neophodno identifikovati KFU i analizirati značajnost različitih faktora koji utiču na us pešnost novih jela u gas tronomskoj ponudi restorana. Upitnik se sastojao od tri dela: profil menadžera, profil restorana i KFU. Za rangiranje KFU (des et stavki) menadžeri beogradskih restorana $(\mathrm{N}=64)$ su koristili Likertovu skalu. Prema njihovom mišljenju, sedam KFU je veoma važno za uspešnost novih jela.

Ključne reči: beogradski restorani, kritični faktori uspešnosti, nova jela JEL klasifikacija: L83

* bozicaleks@gmail.com

This article is an open access article distributed under the terms and conditions of the Creative Commons Attribution (CC BY) license (http://creativecommons.org/licenses/by/4.0/). 


\section{Introduction}

In order to achieve a high levelstandards in the field of restaurant business and boost the competitiveness of restaurants, this industry must adapt to modern trends and introduce an innovative business approach (Ottenbacher \& Harrington, 2009). Such a business approach can be achieved in different ways by introducing: 1) culinary innovations (Gagić, 2016; Lee et al., 2016; Munjal et al, 2016), 2) innovative equipment (Albors-Garrigos et al., 2013), 3) innovative services (Chou et al., 2018; Lee et al., 2016), 4) innovative food preparation and serving techniques (Albors-Garrigos et al., 2013), 5) marketing innovations (Iorgulescu \& Sidonia Rvar, 2013; Lee et al., 2016), 6) innovative design and atmosphere (Horng et al., 2013; Ivkov et al., 2016), 7) innovative technologies (Shcherbak, 2016), 8) innovation in management (Lee et al. al., 2016; Schcherbak, 2016), 9) eco-innovation (Sharma et al., 2020) and etc. At present, the availability of socialmedia platforms (Facebook, Twitter, Pinterest, YouTube, Google+, Instagram, LinkedIn, Foursquare, etc.) (Božić \& Zubanov, 2018), offers great possibilities of their use for innovative marketing. Although all innovations are significant and can contribute to the success of a restaurant, the guests most frequently notice innovations related to the gastronomic offer, primarily the new dis hes (culinary innovations) and new techniques of food preparation. Lee et al. (2016) indicate that top restaurants are expected to setstandards for culinary innovations, which is crucial for building restaurant identity and long-termsuccess. Harrington (2004) created a model for the development of culinary products, which includes the following steps: formulation of culinary innovations, implementation of culinary innovations, evaluation, control and introduction of innovations. Munjal et al. (2016) believe that nowadays innovations in culinary practice are mainly focused on sustainability, care for the environment and the value of tradition, as well as cultural heritage. Given the growing importance of sustainability, much attention is given to the revitalization of traditional diets and cuisines. Accordingly, the gastronomic offer is becoming increasingly important as a part of the cultural heritage. In this respect, Sharma (2012) recognizes the potential and demand for traditional dishes.

Many culinary innovations are based on the use of specific, often very unusual ingredients in food preparation (algae, sprouts, microgreens, edible flowers, edible insects) (Choe et al., 2018; Dobermann et al., 2017; Ebert, 2012; Egebjerg et al., 2018; Ghosh et al., 2018; Mouritsen et al., 2018; Renna et al., 2017; Rioux et al., 2017) or eliminating some ingredients (meat, gluten-containing ingredients, ingredients containing lactose, energy-rich fatty ingredients, sugars, etc.) that are considered bad for consumers' health (Bellis le et al., 2018; Kozonova et al., 2019; Tas et al., 2019). Božić and Milošević (2020) found that in a large number of Belgrade res taurants, microgreens (edible young plants that are harvested 7 14 days after germination when they have developed only cotyledons or a pair of true developed leaves) are used to decorate dishes. Innovations of this type attach great importance to the health aspect, i.e., they are aimed at preparing food that has a positive effect on human health, dis ease prevention and contributes to improving the quality of life. According to certain studies, the perception of food as "healthy" is a bas ic attribute of quality that positively affects the attitudes of guests towards that food (Hur \& Jang, 2015; Kim et al., 2013).

Although culinary innovations can significantly improve restaurant success, the contribution of different new dishes varies. Namely, the success of new dis hes depends on several factors. Previous studies (Kawasaki \& Shimomura, 2015; Kawasaki et al., 2015; Klos se et al., 2004) examined CSFs in the Netherlands and Japan, however, thus far, this topic has not been researched in Serbia and the southeastern region of Europe. In addition, previous studies did not analyze the hierarchy of identified CSFs, therefore, their importance for the success of new dis hes which are part of the gastronomic offer is not known. The main research question of this study is: What are the mos timportant critical success factors (CSFs) of new dishes in 
restaurants? The aimof this study was to analyze the critical factors that are important for the success of new dishes included in the gastronomic offer of Belgrade restaurants.

\section{Theoretical background}

Although food is a basic physiological need, it also plays a role in the success of a restaurant's business. Namely, good food is the basic criterion for the guests' choice of a restaurant (Sulek \& Hensley, 2004). Bernardo et al. (2018) point out that high cuisine, i.e., the offer of top-quality food, is a specific factor in the success of high-quality restaurants. Soriano (2002), as well as Josiamand Monteiro (2004), agree that the unique food taste and ingredients havean important role in the guests' choice of a particular restaurant. Also, Le and Needham (2019) researched the reviews posted on the websites of different restaurants, as well as comments on social media platforms, and found that as far as the guests were concerned, the tas te and quality of food were decisive for the restaurant choice. Another research, conducted almost three decades ago (Auty, 1992), indicates that from that period until today, nothing has changed in the relation between the guests and the gastronomic offer. Namely, in that period, as well as today, food was one of the most important factors for the consumers' choice of restaurants.

In terms of the introduction of new dis hes in restaurant gastronomic offer, it is important to ensure that they will be accepted by the guests. Also, important attributes of food, on which the choice by the guests depends, can be classified into six categories: 1) energy content, 2) nutrient content/health properties, 3) taste, 4) prestige status/properties, 5) ecological, political and ethical characteristics and 6) attributes of time/convenience (Jang et al., 2009).

The success of new dishes depends on several factors identified and analyzed by some authors (Kawasaki \& Shimomura, 2015; Kawasaki et al., 2015; Klosse et al., 2004). Based on the interviews with 18 chefs and analy sis of 63 dishes, sixcritical success factors (CSFs) were identified by Klos se et al. (2004). These CSFs are very significant for the development of new dishes or the improvement of existing ones. The main CSFs are: "(1) name and presentation befitting expectations, (2) appetizing smell suitable to the food, (3) good balance of flavor compounds in relation to the food, (4) presence of umami, (5) a mix of hard and soft textures apparent in the mouth, and (6) high flavor richness" (Klos se et al., 2004, p. 107). Other authors identified ten CSFs based on the analysis published in a culinary magazine for chefs and by application of laddering technique (Kawasaki et al., 2015). These CSFs are: "utilization of main ingredient texture, utilization of main ingredient flavor, utilization of main ingredient umami, featured main in gredient, good pairings (complements) between main and secondary ingredients, not too rich, good balance, cuisine more Japanese in style, elegance and surprise)" (Kawasaki et al., 2015. p. 3). Lis ted CSFs were used for the research of new dishes success factors presented in this paper.

\section{Research methodology}

A questionnaire was developed to estimate critical factors for the success of new dishes in the gastronomic offer of restaurants. This questionnaire consists of three sections. The first section includes questions regarding the profile of managers (age, education, and work experience), the second focuses on the restaurants' profile, while the third refers to culinary success factors. The factors used in the questionnaire were taken from the study conducted by Kawas aki et al. (2015): "Cognitive structures based on culinary success factors in the development of new dishes by Japanese chefs at fine dining restaurants". Therefore, the third part of the questionnaire consisted of ten closed-ended Likert-type questions rating the factors and one open-ended question. The CSF8 (Dish in the style of Serbian cuisine) was adapted to thelocal situation. The research was conducted in November 2020. The analyzed 
Belgrade restaurants were selected using Tripadvis or - the world's largest internet travel platform. When entering keywords "restaurant" and "Belgrade", the portal singles out a wide range of hospitality facilities (1701) on the territory of Belgrade, as well as in suburban municipalities. After eliminating the facilities located in suburban municipalities, 1052 facilities were identified. After another elimination of service restaurants operating under institutions, clubs or cafeterias, fast-food restaurants, temporarily closed facilities, some bakeries and other non-typical facilities, 424 facilities were classified as a classical restaurant. The questionnaire was sent to 200 managers of randomly selected restaurants by e-mail on the e-mail addresses published on the Tripadvis or site, asking them to fill it out and return it to the sender. In order to improve responses, e-mails were followed up with phone calls. All participants were asked the same questions in the same order. The participants ranked each factor with res pect to its importance for the success of a dis h using a Likert scale of 1 (not important) to 5 (very important). Managers were also asked to identify any other important factors not included in the provided list. The final res ponse sample size was 66, however, due to incomplete questionnaires, 2 were discarded from further analyses. Therefore, the final size of the used sample was 64 and the response rate was $32 \%$, which is in accordance with similar studies (Agarwal \& Dahm, 2015; Mandabach et al., 2011).

All data analy ses were done using the One-way ANOVA, t-test and Factor Analysis (using statisticalpackage STATISTIKA 5.0). In addition, the scale reliability was analyzed using Cronbach's Alpha statistics.

\section{Results and discussion}

\subsection{Profile of respondents}

Table 1 profiles the res pondents, presenting the basic data about their age, education and professional experience. The average age of respondents was 44, while the highest percentage of respondents was between 41 and 50 (43.8\%) years of age. Also, a high percentage of respondents $(34.3 \%)$ were between 31 and 40 . More than half $(59.3 \%)$ of respondents completed some high school, significant number of respondents $(37.5 \%)$ had bachelor's degree, while only $3.2 \%$ had master's degrees. Most of them $(70.3 \%)$ had professional education in hospitality. Generally, respondents are well experienced in hospitality. Namely, most of them $(64.0 \%)$ have more than 10 year's experience in hospitality.

Table 1: Profile of respondents

\begin{tabular}{|c|c|c|c|}
\hline \multirow{4}{*}{ Age (year) } & & $\begin{array}{c}\text { Number of } \\
\text { respondents }\end{array}$ & $\begin{array}{c}\text { Percent of } \\
\text { respondents \% }\end{array}$ \\
\hline & $<30$ & 2 & 3.2 \\
\cline { 2 - 4 } & $31-40$ & 22 & 34.3 \\
\cline { 2 - 4 } & $41-50$ & 28 & 43.8 \\
\hline \multirow{3}{*}{ Education } & $>50$ & 12 & 18.7 \\
\cline { 2 - 4 } & High school & 38 & 59.3 \\
\cline { 2 - 4 } & Bachelor degree & 24 & 37.5 \\
\hline \multirow{3}{*}{$\begin{array}{c}\text { Experience in hospitality } \\
\text { (year) }\end{array}$} & $1-5$ & 2 & 3.2 \\
\cline { 2 - 4 } & $6-10$ & 3 & 4.7 \\
\cline { 2 - 4 } & $>10$ & 20 & 31.3 \\
\hline $\begin{array}{c}\text { Professional education in } \\
\text { hospitality }\end{array}$ & Yes & 41 & 64.0 \\
\cline { 2 - 4 } & No & 19 & 70.3 \\
\hline
\end{tabular}

Source: Author's research 


\subsection{Restaurant profile}

The restaurant profile is defined based on several criteria, including the type of cuisine, size and how long the restaurant has stayed in business. Depending on the type of cuisine, the restaurants are clas sified into eight groups (Figure 1). Most restaurants belong to the type of international (36\%) or national (31) cuisine. Then, there are restaurants with European (95), Italian (8\%), Asian (6\%) and Mediterranean (5\%) cuisine, followed by fish restaurants $(3 \%)$. The remaining $2 \%$ include restaurants offering some other type of cuisine, which is not indicated in the questionnaire.

The size of the restaurant is defined based on the number of available seats (chairs). According to these criteria, all restaurants are divided into three groups (Figure 2). Almost half of the restaurants (47\%) belong to the medium size restaurants (50-100 available chairs), while the other half consists of the restaurants that belong to two other groups, which have almost equal share (28\% in the category of big restaurants with more than 100 chairs and $25 \%$ in the category of small restaurants with less than 50 chairs).

In relation to how long the restaurant has stayed in business, restaurants are divided into three groups (Figure 3). The restaurants that have stayed in business for more than 10 years have the highest share in this respect $-48 \%$ and are followed by the restaurants (33\%) which have been in business between 3 and 10 years, and finally younger restaurants (19\%) which have been operating for less than 3 years.

Figure 1: Type of cuisine

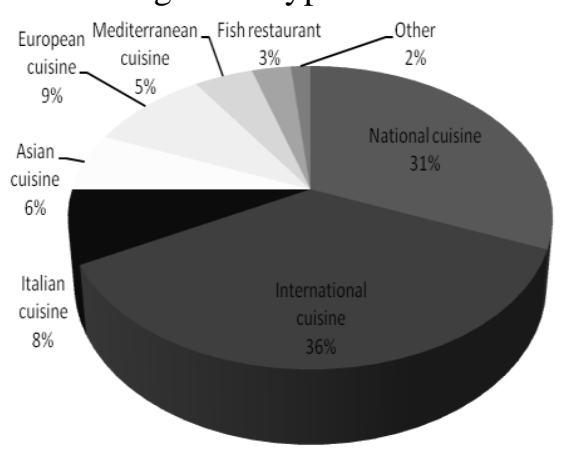

Source: Author's research

Figure 3: How long the restaurant has stayed in business

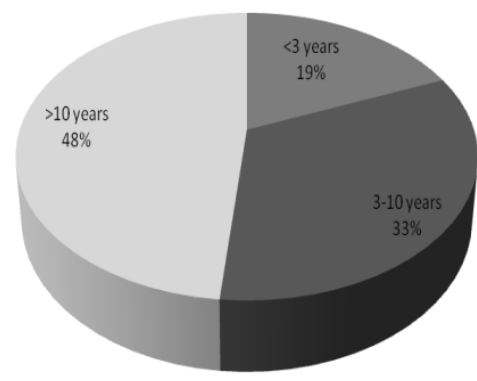

Figure 2: Size of restaurant

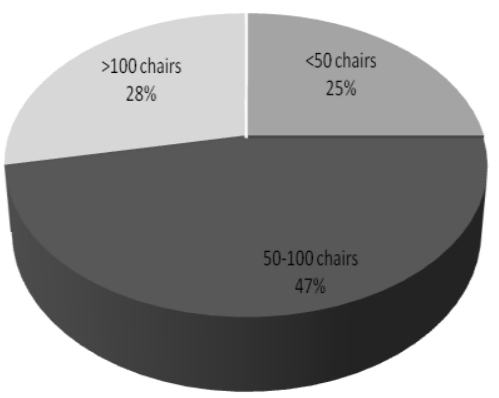

Source: Author's res earch

Source: Author's research 


\subsection{Critical success factors}

In order to evaluate the importance of critical success factors for new dis hes included in the gastronomic offer of Belgrade restaurants, the estimation of the importance of 10 offered CSFs was done by the restaurant managers. Based on the responses provided by the respondents, 10CSFs were ranked according to their importance. Therefore, b ased on the analys is of descriptive parameters of allv ariables used to collect data on factors (10 items) influencing the new dishes success in 64 surveyed Belgrade restaurants (Table 2), it was determined to what extent (based on the assess ment of the surveyed managers), individual items are recognized as significant factors of new dishes success.

According to the analy sis of descriptive parameters, out of 10 offered success factors of new dishes, Belgrade restaurant managers singled out 7 factors whose scalar averages (Mean) range from 4.00 to 4.78 , which means that restaurant managers recognized these factors as crucial for the success of new dishes. On the list of 10 success factors, "Main ingredient umami" occupies the first position with an average score of 4.78. Slightly lower values of scalar averages were determined for the following CSFs: "Main ingredient flavor" - 4.66; "Good balance between taste and texture of ingredients" - 4.56; "Elegance, sophisticated impression" - 4.13; "Good pairings between main and secondary ingredients" - 4.11; "Suprise (unusual food experience)" - 4.04 and Main ingredient texture - 4.00. For two CSFs ("Main ingredient" and "Not too heavy, neither too strong in taste nor too much fat"), the scalar averages had a value between 3 and 4, which means that restaurant managers rate these CSFs as less significant compared to the first 7, however, they are classified as important indicators. The only CSF whose scalar average is below 3 is "Dish in style of Serbian cuisine", which is rated as the least significant CSF.

Table 2: Importance of critical success factors for new dishes in the gastronomic offer of Belgrade restaurants

\begin{tabular}{|c|l|c|c|c|}
\hline Position & \multicolumn{1}{|c|}{ CSFs } & Mean & SD & SE \\
\hline 01. & Main ingredient umami & $\mathbf{4 . 7 8}$ & 0.744 & 0.052 \\
\hline 02. & Main ingredient flavor & $\mathbf{4 . 6 6}$ & 0.720 & 0.088 \\
\hline 03. & $\begin{array}{l}\text { Good balance between taste and text ure of } \\
\text { ingredients }\end{array}$ & $\mathbf{4 . 5 6}$ & 0.641 & 0.048 \\
\hline 04. & Elegance, sophisticated impression & $\mathbf{4 . 1 3}$ & 0.906 & 0.060 \\
\hline 05. & $\begin{array}{l}\text { Good pairings between main and secondary } \\
\text { ingredients }\end{array}$ & $\mathbf{4 . 1 1}$ & 0.936 & 0.067 \\
\hline 06. & Surprise (unusual food experience) & $\mathbf{4 . 0 4}$ & 0.852 & 0.055 \\
\hline 07. & Main ingredient texture & $\mathbf{4 . 0 0}$ & 0.778 & 0.056 \\
\hline 08. & Main ingredient & $\mathbf{3 . 6 6}$ & 1.022 & 0.085 \\
\hline 09. & $\begin{array}{l}\text { Not too heavy, neither too strong in taste nor } \\
\text { too much fat }\end{array}$ & $\mathbf{3 . 3 3}$ & 1.197 & 0.078 \\
\hline 10. & Dish in style of Serbian cuisine & $\mathbf{2 . 0 0}$ & 0.055 & 0.085 \\
\hline
\end{tabular}

Notes: 1=not important; 5= extremely important; SD - standard deviation; SE - standard error

Source: Author's research

Factor analysis (Table 3) of 10 CFSs found that five variables related to food ingredients (main ingredient umami; main in gredient flavor; good balance between taste and texture of ingredients; good pairings between main and secondary ingredients; main ingredient) participate in the formation of the first component, which is named as Characteristics of ingredients. The remaining three CFSs (elegance, sophis ticated impres sion; s urprise (unusual 
food experience); not too heavy, neither too strong in taster nor too much fat) create second component entitled Impression about dish.

Table 3: Results of factor analysis

\begin{tabular}{|c|c|c|c|c|}
\hline Factors & $\begin{array}{c}\text { Factor } \\
\text { loading }\end{array}$ & Eigenvalue & $\begin{array}{c}\% \text { of } \\
\text { variance } \\
\text { explained }\end{array}$ & $\begin{array}{l}\text { Cronbach's } \\
\text { alpha }\end{array}$ \\
\hline $\begin{array}{l}\text { F1: Characteristics of ingredients } \\
\text { Main ingredient flavor } \\
\text { Main ingredient } \\
\text { Main ingredient umami } \\
\text { Good pairings between main and } \\
\text { secondary ingredients } \\
\text { Good balance between taste and } \\
\text { texture of ingredients }\end{array}$ & $\begin{array}{l}0.821 \\
0.745 \\
0.705 \\
0.630 \\
\\
0.581\end{array}$ & 3.010 & 25.112 & 0.897 \\
\hline $\begin{array}{l}\text { F2: Impression about the dish } \\
\text { Surprise (unusual food experience) } \\
\text { Not too heavy, neither too strong in } \\
\text { taste nor too much fat } \\
\text { Elegance, sophisticated impression }\end{array}$ & $\begin{array}{l}0.722 \\
0.614 \\
0.570\end{array}$ & 1.705 & 14.134 & 0.812 \\
\hline
\end{tabular}

Source: Author's res earch

Differences between managers' viewpoints on the importance of Characteristics of ingredients and Impression about the dish for the success of new dishes in the gastronomic offer, depending on their education (leveland area) and the experience and type of cuis ine, were analyzed using the t-test. In this respect, in some categories (education level and experience) a s maller number of managers (les s than $10 \%$ of the total sample) were included; the analysis encompasses only those groups of managers who participate with more than $10 \%$ in the total sample (education level: high school and bachelor degree; experience: 6-10 years and more than 10 years; type of cuisine: national and international). The obtained results show that there are significant differences between managers who finished high school and their colleagues with bachelor's level of education regarding the Impression about the dish (Table 4). These results indicate that there are statistically significant differences in the managers' viewpoints according to their level of education for the CSFs "Suprise (unusual food experience)" and "Elegance, sophisticated impression" at significance levelp $<0.05$. Both CSFs are rated higher by managers with high school degrees (Table 4). Differences between the two groups of manages were not confirmed for Characteristics of ingredients.

Table 4: Results of the t-test according to the education level

\begin{tabular}{|l|c|c|c|}
\hline \multirow{2}{*}{ Impression about the dish } & \multicolumn{2}{|c|}{ Mean value } & \multirow{2}{*}{ t-test } \\
\cline { 2 - 3 } & High school & Bachelor & $0.024^{*}$ \\
\hline Surprise (unusual food experience) & 4.36 & 3.78 & 0.589 \\
\hline $\begin{array}{c}\text { Not too heavy, neither too strong } \\
\text { in taste nor too much fat }\end{array}$ & 3,29 & 3.43 & $0.009^{*}$ \\
\hline Elegance, sophisticated impression & 4.43 & 3.76 & \\
\hline
\end{tabular}

Source: Author's research

Between managers with education in hospitality and managers with education in some other areas, there were no significant differences relating to the Impression about dish. T-test shows significant differences between these two groups of managers concerning the Characteris tics of ingredients (Table 5). Namely, there are statistically significant differences 
Božić, A., Milošević, S. - Critical success factors for new dishes in gastronomic offer of Belgrade restaurants Hotel and Tourism Management, 2021, Vol. 9, No. 2: 51-62.

in the managers' viewpoints according to their education field for CSFs "Main ingredient flavor" and "Main ingredient umami" at significance level $\mathrm{p}<0.05$. These CSFs are rated higher by the managers whose education is hos pitality related (Table 5).

Table 5: Results of the t-test according to the education field

\begin{tabular}{|l|c|c|c|}
\hline \multirow{2}{*}{ Characteristics of ingredients } & \multicolumn{2}{|c|}{ Mean value } & \multirow{2}{*}{ t-test } \\
\cline { 2 - 3 } & $\begin{array}{c}\text { Education in } \\
\text { hospitality }\end{array}$ & $\begin{array}{c}\text { Education out of } \\
\text { hospitality }\end{array}$ & \\
\hline Main ingredient flavor & 4.89 & 3.96 & $0.007^{*}$ \\
\hline Main ingredient & 3.74 & 3.58 & 0.118 \\
\hline Main ingredient umami & 4.88 & 4.23 & $0.041^{*}$ \\
\hline $\begin{array}{c}\text { Good pairings between main and } \\
\text { secondary ingredients }\end{array}$ & 4.18 & 3.93 & 0.428 \\
\hline $\begin{array}{c}\text { Good balance between taste and } \\
\text { texture of ingredients }\end{array}$ & 4.43 & 4.81 & 0.312 \\
\hline
\end{tabular}

Source: Author's research

Managers' viewpoints about importance of Characteris tics of ingredients and Impression about the dish for the success of new dishes are not dependent on their experience in hos pitality and type of cuisine. T-testhas not identified differences between managers with six to ten years of experience and managers with more than 10 years of experience. Also, results of the t-test according to the type of cuisine show that there are no differences in restaurant managers' viewpoints about the importance of Characteristics of ingredients and Impression about the dish for the success of new dis hes in the gastronomic offer depending on the type of cuisine (national or international).

One-way ANOVA was used to analyze differences in restaurant managers' viewpoints about the importance of Characteristics of ingredients and Impres sion about the dis $h$ for the success of new dis hes in the gastronomic offer depending on their age, size of the res taurant and how long has the restaurant stayed in business. In this regard, in the category "less than 30 years" pertaining to the age of managers, a smaller number of respondents (less than $10 \%$ of the total sample) were included; the analysis included only those groups of respondents who participated with more than $10 \%$ in the total sample (31-40, $41-50$ and over 50 years). A statis tically significant difference at the level of $\mathrm{p}<0.05$ concerning the managers belonging to different age groups was found only for Characteristics of ingredients (Table 6), while there were no significant differences for Impres sion about the dish. Post-hoc comparis ons using the Tukey testindicated significant differences in viewpoints between the managers aged 31-40 and the managers aged 41-50 for the following CSFs: "main ingredient flavor" $(\mathrm{p}=0.021<0.05)$ and "main ingredient" $(\mathrm{p}=0.032<0.05)$. Also, the Tukey test pointed to significant differences between managers aged $31-40$ and those over 50 years of age for the following CSFs : "main ingredient flavor" $(p=0.034<0.05)$ and "goodbalance between taste and texture of ingredients" $(\mathrm{p}=0.019<0.05)$.

Table 6: Results of ANOVA according to the age of managers

\begin{tabular}{|c|c|c|c|c|c|}
\hline \multirow{2}{*}{ Characteristics of ingredients } & \multicolumn{3}{|c|}{ Mean value } & \multirow[b]{2}{*}{$\mathbf{F}$} & \multirow[b]{2}{*}{$\mathbf{p}$} \\
\hline & $31-40$ & 41-50 & $>\mathbf{5 0}$ & & \\
\hline Main ingredient flavor & 4.21 & 4.89 & 4.78 & 6.312 & $0.006^{*}$ \\
\hline Main ingredient & 3.63 & 3.45 & 4.21 & 3.687 & $0.023^{*}$ \\
\hline Main ingredient umami & 4.73 & 4.84 & 4.69 & 1.759 & 0.152 \\
\hline $\begin{array}{l}\text { Good pairings between main and } \\
\text { secondary ingredients }\end{array}$ & 3.98 & 4.19 & 4.09 & 0.321 & 0.723 \\
\hline $\begin{array}{l}\text { Good balance between taste and } \\
\text { texture of ingredients }\end{array}$ & 4.78 & 4.46 & 4.01 & 5.468 & $0.009 *$ \\
\hline
\end{tabular}

Source: Author's research 
According to the results of ANOVA, there are statistically significant differences in the managers' viewpoints according to the size of a restaurant in terms of the Impression about the dish and only for one CSF (Table 7), while there are no significant differences for Characteris tics of ingredients. The results of the Tukey post-hoctest indicated that there are significant differences in viewpoints between the managers employed in restaurants with less than 50 chairs and those working in restaurants with more than 100 chairs concerning the CSF "Suprise (unusual food experience)" $(\mathrm{p}=0.027<0.05)$.

Table 7: Results of ANOVA according to the size of a restaurant

\begin{tabular}{|c|c|c|c|c|c|}
\hline \multirow[b]{2}{*}{ Impression about the dish } & \multicolumn{3}{|c|}{ Mean value } & \multirow[b]{2}{*}{$\mathbf{F}$} & \multirow[b]{2}{*}{$\mathbf{p}$} \\
\hline & $\begin{array}{l}<\mathbf{5 0} \\
\text { chairs }\end{array}$ & $\begin{array}{l}50-100 \\
\text { chairs }\end{array}$ & $\begin{array}{l}>100 \\
\text { chairs }\end{array}$ & & \\
\hline Surprise (unusual food experience) & 4.69 & 4.01 & 3.79 & 3.521 & $0.031 *$ \\
\hline $\begin{array}{l}\text { Not too heavy, neither too strong } \\
\text { in taste nor too much fat }\end{array}$ & 3.32 & 3.25 & 3.48 & 1.153 & 0.328 \\
\hline Elegance, sophisticated impression & 4.02 & 4.16 & 4.12 & 1.947 & 0.152 \\
\hline
\end{tabular}

Source: Author's research

The application of ANOVA for the analysis of statistically significant differences in the managers' viewpoints according to how long has the restaurant stayed in business showed that there are no differences between viewpoints of managers employed in the restaurants which have been in business for different periods of time concerning any of the given CSFs.

\section{Conclusion}

This research presents the findings of the study focusing on critical success factors for new dishes in gas tronomic offers of restaurants from the perspective of managers of Belgrade restaurants. It provides the answer to the main research question. Based on the results of the study, several conclusions can be drawn. First, the majority of analyzed CSFs (7/10) were estimated by the managers of Belgrade restaurants as crucial for new dishes success. Many of these CSFs are related to the ingredients of new dishes, and primarily to the main ingredient. Although the "main ingredient" had a low ranking (08) in the CSFs hierarchy, some parameters (main ingredient umami, main ingredient flavor, main ingredient texture) related to the main ingredient are better positioned, and the "main ingredient umami" was selected as the most important. Factor Analys is showed that six variables related to food ingredients support the first component entitled Characteristics of ingredients, while the remaining variables support the second component entitled Impression about the dish. The influence of seven independent variables on the first and second components were different. Namely, the attitude of managers of different ages, levels and fields of education and working in restaurants of different sizes varied, while significant differences were not identified between the managers depending on their experience, the restaurant's type of cuisine and the restaurant's duration.

Our study contributes to previous research of CSFs of new dishes, since the latter did not analyze the effect of managers' and restaurants' profiles on their attitudes about new dis hes success. Also, previous studies were focused on the identification of the CSFs, while this study es timated the importance of already identified CSFs. The obtained results contribute to the science of restaurantbusiness in our country which has not examined the CSFs of new dishes thus far. The practical implications of the research are reflected in the fact that the results of this study might prove valuable to current and future owners of restaurant 
businesses. Business owners can improve their business performance by applying knowledge from this study.

The limitations of the research conducted in this paper are related to very scarce literature on the given subject, which is necessary for the design of the research ins trument. Also, in terms of future studies, the comparison of the results relating to assessing the significance of different CSFs from different pers pectives (guest perspectives and managerial ones) would provide greater reliability of the obtained results.

\section{Conflict of interest}

The authors declare no conflict of interest.

\section{References}

1. Agarwal, R., \& Dahm, M. J. (2015). Success factors in independent ethnic restaurants. Journal of Foodservice Business Research, 18(1), 20-33. https://doi.org/10.1080/15378020.2015.995749

2. Albors-Garrigos, J., Barreto, V., García-Segovia, P., Martínez-Monzó, J., \& HervásOliver, J. L. (2013). Creativity and innovation patterns of haute cuisine chefs. Journal of Culinary Science \& Technology, 11(1), 19-35. https://doi.org/10.1080/15428052.2012.728978

3. Auty, S. (1992). Consumer choice and segmentation in the restaurant industry. The Service Industries Journal, 12(3), 324-339. https://doi.org/10.1080/02642069200000042

4. Bellis le, F., Hébel, P., Fourniret, A., \& Sau vage, E. (2018). Consumption of $100 \%$ pure fruit juice and dietary quality in French adults: Analysis of a nationally representative survey in the context of the WHO recommended limitation of free sugars. Nutrients, 10(4), 459. https://doi.org/10.3390/nu 10040459

5. Bernardo, M., Escalante, R., \& Arbussà A. (2018). Analysis of the Catalan haute cuisine success: The role of education and network creation. Journal of Evolutionary Studies in Business, 3(1), 84-111. https://doi.org/10.1344/jesb2018.1.j038

6. Božić, A., \& Milošević, S. (2020). Microgreens in gastronomic offer of Belgrade restaurants. In D. Cvijanović et al. (Eds.). Tourism in Function of Development of the Republic of Serbia - Tourism and Rural Development. Thematic Proceedings I (pp. 94 111). Vrnjačka Banja: Faculty of Hotel Management and Tourism in Vrnjačka Banja.

7. Božić, A., \& Zubanov, V. (2018). Značaj društvenih mreža u komunikaciji sa korisnicima usluga u modernom restoraterstvu [Significance of social networks in communication with service users in modern catering industry]. Tims. Acta, 12(1), 25 35. https://doi.org/10.5937/timsact12-15910

8. Choe, U., Yu, L., \& Wang, T. T. Y. (2018). The science behind microgreens as an exciting new food for the $21^{\text {th }}$ century. Journal of Agricultural and Food Chemistry, 66(44), 11519-11530. https://doi.org/10.1021/acs.jafc.8b03096

9. Chou, S.-F., Horng, J.-S., Liu, C.-H., \& Gan, B. (2018). Explicating restaurant performance: The nature and foundations of sustainable service and organizational environment. International Journal of Hospitality Management, 72, 56-66. https://doi.org/10.1016/j.ijhm.2018.01.004

10. DeVellis, R. F. (2003). Scale development: Theoryandapplications (2nd ed.). Thousand Oaks, California: Sage. 
11. Dobermann, D., Swift, J. A., \& Field, L. M. (2017). Opportunities and hurdles of edible insects for food and feed. Nutrition Bulletin, 42(4), 293308. https://doi.org/10.1111/nbu.12291

12. Ebert, A. (2012). Sprouts, microgreens, and edible flowers: The potential for high value specialty produce in Asia. Regional Symposium on High Value Vegetables in Southeast Asia: Production, Supply and Demand (SEAVEG2012) (pp. 216-227). Chiang Mai, Thailand, AVRDC - The World Vegetable Center

13. Egebjerg, M. M., Olesen, P. T., Eriksen, F. D., Ravn-Haren, G., Bredsdorff, L., \& Pilegaard, K. (2018). Are wild and cultivated flowers served in restaurants or sold by local producers in Denmark safe for the consumer? Food and Chemical Toxicology, 120, 129-142. https://doi.org/10.1016/j.fct.2018.07.007

14. Gagić, S. (2016). Restaurant innovativeness: A case study of Vojvodina. The European Journal of Applied Economics, 13(2), 57-69.

15. Ghosh, S., Jung, C., \& Meyer-Rochow, V. B. (2018). What governs selection and acceptance of edible insect species? In A. Halloran et al. (Eds.), Edible Insects in Sustainable Food Systems (pp. 331-351). Cham, Germany: Springer Publishing.

16. Harrington, R. J. (2004). Part I: The culinary innovation proces s, a barrier to imitation. Journal of Foodservice Business Research, 7(3), 35-57. https://doi.org/10.1300/J369v07n03_04

17. Horng, J. S., Chou, S. F., Liu, C. H., \& Tsai, C. Y. (2013). Creativity, aesthetics and eco-friendliness: A physical dining environment design synthetic ass ess ment model of innovative restaurants. Tourism Management, 36(C), 15-25. https://doi.org/10.1016/j.tourman.2012.11.002

18. Hur, J., \& Jang, S. S. (2015). Consumers' inference-dynamics about healthy menu promotions in a bundle context. International Journal of Hospitality Management, 44, 12-22. https://doi.org/10.1016/i.iihm.2014.09.006

19. Iorgulescu, M. C., \& Sidonia Rvar, A. (2013). Measuring managers' perception of innovation in the Romanian hospitality industry. Procedia Economics and Finance, 6, 512-522. https://doi.org/10.1016/S2212-5671(13)00169-X

20. Ivkov, M., Blešić, I., Simat, K., Demirović, D., Božić, S., \& Stefanović, V. (2016). Innovations in the restaurant industry: An exploratory study. Economics of Agriculture, 63(4), 1169-1186. https://doi.org/10.5937/ekoPolj1604169I

21. Jang, S. C. S., Ha, A., \& Silkes, C. A. (2009). Perceived attributes of Asian foods: From the perspective of the American customers. International Journal of Hospitality Management, 28(1), 63-70. https ://doi.org/10.1016/j.ijhm.2008.03.007

22. Josiam, B. M., \& Monteiro, P. A. (2004). Tandoori tastes: Perceptions of Indian restaurants in America. International Journal of Contemporary Hospitality Management, 16(1), 18-26. https://doi.org/10.1108/09596110410516525

23. Kawasaki, H., \& Shimomura, K. (2015). Temporal design of taste and flavor: practical collaboration between chef and scientist. Flavour, 4(12), 1-4. https://doi.org/10.1186/2044-7248-4-12

24. Kawasaki, H., Kasamatsu, C., \& Nonaka, M. (2015). Cognitive structures based on culinary success factors in the development of new dishes by Japanese chefs at fine dining restaurants. Flavour, 4(1), 1-10. https://doi.org/10.1186/2044-7248-4-1

25. Kim, H. J., Park, J., Kim, M. J., \& Ryu, K. (2013). Does perceived restaurant food healthiness matter? Its influence on value, satis faction and revisit intentions in restaurant operations in South Korea. International Journal of Hospitality Management, 33, 397405. https://doi.org/10.1016/j.ijhm.2012.10.010

26. Klos se, P. R., Riga, J., Cramwinckel, A. B., \& Saris, W. H. M. (2004). The formulation and evaluation of culinary success factors (CSFs) that determine the palatability of food. Food Service Technology, 4(3), 107-115. https://doi.org/10.1111/j.14715740.2004.00097.x 
27. Kozonova, J., Stepanova, V., Salavelis, A., \& Kulyk, A. (2019). Sweet ices with high nutritional value. In V. Nadykto (Ed.) Modern Development Paths of Agricultural Production: Trends and Innovations (pp. 729-736). Switzerland: Springer International Publishing.

28. Le, P. N., \& Needham, C. R. (2019). Factors contributing to the success of ethnic restaurant businesses in Canada. Open Journal of Business and Management, 7(4), 1586-1609. https://doi.org/10.4236/ojbm.2019.74110

29. Lee, C., Hallak, R., \& Sardeshmukh, S. R. (2016). Innovation, entrepreneurship, and restaurant performance: A higher-order structural model. Tourism Management, 53, 215-228. https://doi.org/10.1016/j.tourman.2015.09.017

30. Mandabach, K. H., Siddiqui, M. A., Blanch, G. F., \& VanLeeuwen, D. M. (2011). Restaurant viability: Operations rating of contributing success factors. Journal of Culinary Science \& Technology, 9(2), 71-84.

31. Mouritsen, O. G., Rhatigan, P., \& Pérez-Lloréns, J. L. (2018). The rise of seaweed gastronomy: phycogastronomy. Botanica Marina, 62(3), 195-209. https://doi.org/10,1515/BOT-2018-0041

32. Munjal, S., Sharma, S., \& Menon, P. (2016). Moving towards "Slow Food", the new frontier of culinary innovation in India. Worldwide Hospitality and Tourism Themes, $8(4), 444-460$.

33. Ottenbacher, M. C., \& Harrington, R. J. (2009). The product innovation process of quick-service restaurant chains. International Journal of Contemporary Hospitality Management, 21(5), 523-541. https://doi.org/10.1108/09596110910967782

34. Renna, M., Di Gioia, F., Leoni, B., Mininni, C., \& Santamaria P. (2017). Culinary as sessment of self produced microgreens as basic ingredients in sweet and savoury dishes. Journal of Culinary Science \& Technology, 15(2), 126-142. https://doi.org/10.1080/15428052.2016.1225534

35. Rioux, L.-E., Beaulieu, L., \& Turgeon, S. L. (2017). Seaweeds: A traditional ingredients for new gastronomic sensation. Food Hydrocolloids, 68, 255-265. https://doi.org/10.1016/j.foodhyd.2017.02.005

36. Sharma, S. (2012). Gastronomic touris m in Old Delhi. Context, 9(2), 53-64.

37. Sharma, T., Chen, J., \& Liu, W. (2020). Eco-innovation in hospitality research (19982018): A systematic review. International Journal of Contemporary Hospitality Management, 32(2), 913-933. https://doi.org/10.1108/IJCHM-01-2019-0002

38. Shcherbak, V. (2016). Open innovations as a tool of restaurant business effective activity. Менеджмент [Management], 24, 115-127.

39. Soriano, D. R. (2002). Customers' expectations factors in restaurants: The situation in Spain. International Journal of Quality and Reliability Management, 19(8-9), 10551067. http://dx.doi.org/10.1108/02656710210438122

40. Sulek, J. J., \& Hensley, R. L. (2004). The relative importance of food, atmos phere, and fairness of wait: The case of a full-service restaurant. Cornell Hospitality Quarterly, 45(3), 235-247. https://doi.org/10.1177/0010880404265345

41. Tas, A. A., Umit, N., Alkan, R. O., Boynak, A., \& Yeral, S. D. (2019). Approximation of protein quality (DIAAS) of vegetarian dishes served in restaurants. International Journal of Obesity and Nutritional Science, 1(1), 1-5. https ://doi.org/10.18689/ijons 1000101

Received: 17 May 2021; Sent for revision:21 June 2021; Accepted: 14 November 2021 